\title{
SOME THOUGHTS ON THE DEMISE OF ROMAN INFLUENCE IN NORTH AFRICA, 5th/ 6th CENTURY AD
}

\author{
L Cilliers (University of the Free State, Bloemfontein)
}

\section{Introduction}

When one thinks of the once mighty Roman Empire, a vision of the proverbial "eternal city" of Rome with its beautiful white colonnaded marble buildings comes to mind. However, Rome did not last eternally, in fact, more than 200 years before the traditional date of the "fall" of the Roman Empire in the West (AD 476), the Golden Age of Rome had shifted towards the southern shore of the Mediterranean, to the previously rather neglected provinces of North Africa. From the $2^{\text {nd }}$ century AD until it was overrun by the Vandals in the 5th century, Roman North Africa enjoyed a period of unequalled prosperity; during the Vandal reign Roman influence still endured in small measure, followed by a brief renaissance under the Byzantines in the $6^{\text {th }}$ century, but after the Arab conquest in the late $7^{\text {th }}$ century it vanished as completely as if the Romans had never set foot in North Africa.

The exceptional prosperity of North Africa at a time when the rest of the Empire was already in a state of decline, and the complete disappearance of any Roman influence whatsoever on the culture and language of a region which was at the time the most Romanized of all the Roman provinces, will be discussed in this article.

\section{The rise of Roman North Africa}

The region referred to as "Roman North Africa" comprises a huge stretch of land with a coastline of more than $2600 \mathrm{~km}$ as the crow flies, the distance from Paris to Moscow. During the Roman Empire it consisted of various provinces: from east to west Egypt, Cyrenaica (= modern Libya), Africa Proconsularis (= Tunisia) which also included the narrow coastal strip of Tripolitania (=west Libya), then also Numidia (=Algeria), Mauretania Caesariensis and Mauretania Tingitana (=Morocco). In this article I will concentrate on the central part, namely Africa Proconsularis, and more specifically on its capital, Carthage. ${ }^{1}$

This region became in the $2^{\text {nd }}$, and even more so in the $3^{\text {rd }}$ and $4^{\text {th }}$ centuries $\mathrm{AD}$ an object of envy among the other provinces because of its wealth, since this was a period during which the rest of the Empire was embroiled in political and economic

1 The name Qart Hadasht ("Carthage" was the corrupt Roman version) means "new capital" in Phoenician. The Phoenicians, the first settlers in historical times, came from Tyre in Phoenicia in the $9^{\text {th }}$ century and probably planned it as an alternative capital in the west since Tyre was at this stage seriously harassed by the Assyrians. According to tradition, the Phoenicians founded Carthage in 814 BC. The Greek historian Timaeus records the myth that Carthage was founded by the Phoenician princess Elissa or Dido, who fled from Tyre when her husband was murdered by her brother Pygmalion. Dido is said to have paid the Libyans for as much land as could be covered by an ox-hide (Greek bursa); by cutting the ox-hide in narrow strips and laying them edge to edge in a vast semi-circle, she secured not only a beaching point for her party, but also the hill called "Byrsa" today. Cf. Raven 1969: 12. 
chaos. ${ }^{2}$ The question arises how and why this rather neglected province became so prosperous - it was completely ruined after the Third Punic War, ${ }^{3}$ then left to itself until the time of Caesar in the 40s of the 1st century BC, and even during the Empire seldom visited by the emperors ${ }^{4}$ (it was peaceful, and the rulers of the western world had more urgent matters to attend to, in fact, they were only interested in the uninterrupted annual grain supply for Rome supplied by North Africa).

The old orthodox view of the Socialist historian $\operatorname{Rostovtzeff}^{5}(1957: 535-541)$ that cities in every region of the Empire were in full decline by the 4th century and that the ancient elite were ruined or massacred by the military emperors of the $3^{\text {rd }}$ century, has to be rejected when one looks at the situation in North Africa in the $3^{\text {rd }}$ and $4^{\text {th }}$ centuries. Archaeological excavations in recent years bringing to light the remains of hundreds of magnificent baths, theatres, triumphal arches and gorgeous tombs $^{6}$ and thousands of inscriptions, have led to a radical re-evaluation of Late Roman Africa, and revealed the vitality and prosperity of both cities and countryside, the wealth of the city elite in this period and the luxury of the upper-class homes. ${ }^{7}$

2 The anonymous author of the Expositio totius mundi (quoted by Lepelley 1979: 409 n.1) said that the country is so magnificent because the inhabitants are cheats and liars. Various other contemporary authors also referred to its wealth, e.g. Lactantius who stated that the emperor Maximian was the privileged one in Diocletian's tetrarchy because the region assigned to him was Italy and the rich provinces of Africa and Spain (De la mort des persécuteurs VIII, quoted in Lepelley 1979: 29 n.2). The $5^{\text {th }}$ century African author Victor of Vita stated that the Vandal king Genseric deliberately brought his people to Africa, having traveled through Gaul, Spain and Morocco, because he had heard that it is exceptionally wealthy, "and they found a beautiful country which was flourishing in all respects" (Historia persecutionis Africae provinciae I.1.3, C.S.E.L. VII.3).

3 This is the traditional view. But Lancel 1995:428, looking at the history of Carthage from an archaeological perspective, mentions that it was Niebuhr who at the beginning of the $19^{\text {th }}$ century added the story that Scipio had a plough driven over the ruins of Carthage, and that the episode of the salt scattered over the ruins of Carthage was added by B. L. Hallward in an early $20^{\text {th }}$ century edition of the Cambridge Ancient History. This was probably inspired by the Biblical story in the book of Judges 9:45 where Abimelech is said to have sown salt on the ruins of the town of Sichem which he had destroyed. Lancel also points out that excavations on the slopes of the Byrsa hill have revealed city walls, some of which were still $2 \mathrm{~m}$. in height. Thus it seems that despite Cato's well-known war-cry "Carthago delenda est!" the city was after all not completely destroyed.

4 Some emperors who did visit it were Hadrian, and of course Septimius Severus who grew up in Lepcis Magna in Libya, but after Maximian in 298 it was not visited by an emperor again since it was "a military backwater". Cf. Warmington 1954: 112.

5 This view is based on ancient literary and juridical sources, mentioned and discussed by Lepelley 1979: 22-25. Jones 1964: 712-766 gives a more judicious view.

6 Cf. in this regard Thompson 1969: 132.

7 Lepelley 1979: 101-108 gives a detailed account of the number of new building constructions and the restoration of old buildings in the $4^{\text {th }}$ century under the various emperors, clearly showing much activity and a population increase in this period. The study of mosaics found in the houses of the wealthy supports this view: stylistic and stratigraphic criteria have allowed mosaics formerly assigned to the early imperial period to be more accurately dated to the $4^{\text {th }}$ and $5^{\text {th }}$ centuries. Warmington 1954: 35-38 gives the number of the constructions or repairs of public buildings and works in Africa Proconsularis based on inscriptions (period followed by the number in brackets): 244-284 (7); 284-306 (39); 306-337 (13); 337-363 (14); 363-383 (44); 383429 (18). This clearly shows great activity even up to the beginning of the $5^{\text {th }}$ century. 
In urban centres, Romanization reached it apogee in the $4^{\text {th }}$ century $\mathrm{AD}$ (Lepelley 1979: 409).

\subsection{Romanization}

A short digression on the term "Romanization" is necessary at this point. There has during the past two decades been a heated debate about the role played by the Romans in North Africa. It must at once be stated that North Africa, probably more than any other province of the Roman Empire, is studied against a profound ideological backdrop due to the antipathy of countries such as Tunisia, Libya and Algeria to a colonial past, however remote in time. The colonialist view, represented by Mommsen and others in the $19^{\text {th }}$ and early $20^{\text {th }}$ centuries, held that Romanization led to the betterment of the Roman world by securing peace and bringing development. The post-colonials on the other hand stated that the colonialists "disinherited the North African peoples of their cultural history by ascribing to the immigrants all the positive achievements of Roman Africa, and portraying the Africans either as passive recipients of a superior culture or as a nomadic and lawless people incapable of self-government" (Mattingly \& Hitchner 1995: 170). Fortunately it seems as if the swing of the pendulum between these two extremes has now been arrested somewhere in the middle, so that the contribution of the indigenous population is also recognized. ${ }^{8}$

However, in this debate there is one factor which has perhaps not been estimated in its proper value, namely that throughout her "colonial" history Rome was loth to impose her language, culture, way of life and religion on conquered nations. Her purpose in establishing a colony was usually economic or military Romanization in the sense of getting the local population to adopt Roman political structures and norms, was the least of her concerns. In fact, on the local level, Rome preferred to give the indigenous population as much independence as possible. 9 Furthermore, it was only in towns which had been promoted to the status of colonia or municipium where Latin would become the official language and the government would be constituted on the Roman pattern - and the request to be promoted to this level had to come from the inhabitants of the town itself (the incentive was of course that the citizens could receive limited Roman citizenship and could, among other things, qualify to be elected as magistrates in their town).

8 Urbanization had e.g. already been under way for some centuries when the Romans came; irrigation systems as well as the use of cisterns and water-control dams were also pre-Roman initiatives; several distinct Libyan alphabets were found, indicating that literacy was more widespread in Africa than previously thought. Cf. Fentress 2006: 31; Mattingly \& Hitchner 1995: 172-205.

9 Pikhaus 2006: 99 refers to the long survival of towns whose magistrates were suffetes in the Punic tradition, showing that the Roman administration simply adopted en bloc the Carthaginian systems within the area of Africa Vetus and left the administrative structures pretty much alone. 


\subsection{Agriculture}

The main source of income in this region was agricultural products which were exported. Thanks to the good climate their harvests were reliable; in fact, after barely a century of direct Roman rule during which the expertise to develop the country's infrastructure was provided, this province surpassed Egypt as Rome's principal supplier of corn, and for more than 300 years Africa sent about half a million tons of corn to Rome every year.

In drier regions which were not suitable for cereals or viticulture, the most lucrative agricultural product by far was the olive. Although it takes about ten years for the tree to bear fruit, it requires little upkeep and little labour for a good return. Olive oil was in great demand all over the Empire: it was used for cooking, soap, oil for a rubbing down at the baths, perfume and as fuel for lighting. ${ }^{10}$ The enormous quantity of oil shipped to Italy and the other provinces was thus largely responsible for the country's wealth, ${ }^{11}$ especially after the embargo on the cultivation of the olive and vine to protect the struggling Italian farmers was lifted by the emperor Hadrian in $125 .{ }^{12}$ The manner of its cultivation also suited the pattern of land exploitation at the time - it could support a large population spread over a large area, but not a concentrated one; evidence of this is the huge amphitheatre at Thysdrus (modern El Djem) which, being the centre of a number of peasant villages, could seat 60000 spectators while the population of the town at the time was scarcely half of that.

Other products exported from Africa were pottery for domestic use, ${ }^{13}$ figs from Carthage, ${ }^{14}$ exotic fruits and vegetables like pomegranates, truffles and

10 Cf. St. Augustine's complaint (De ordine X.1.3, C.S.E.L. 63 p.125) that the rooms which he and his friends hired in Milan were not well lit since the oil which was used in the lamps was so expensive that not even the rich could afford it, in contrast to the situation in Africa where he could read and write at night. The thousands of oil lamps excavated in Africa show that oil was easily obtainable and cheap.

11 The story is told that when the country was invaded by the Arabs, the general of the victorious army was amazed at its wealth and asked the local inhabitants about the reason; one citizen is reported to have picked up an olive and, laying it before the general, told him that that little fruit was the cause of all their prosperity (Graham 1902: 307 n.1).

12 It seems that the embargo was not very effective; however, when on a visit to North Africa, Hadrian ordered that as much land as was not already under cultivation should be opened up and that entrepreneurs should be exempted from taxes until their trees were productive (Lennox Manton 1988: 110).

13 The bulk of the ceramic production in North Africa attest to the flourishing period in the $3^{\text {rd }}$ and $4^{\text {th }}$ centuries (Mattingly \& Hitchner 1995:192).

14 Both Plutarch (Cato Maior 27.1) and Pliny (Natural History xv.74) relate that Cato, after his embassy to Carthage in $153 \mathrm{BC}$, at a session of the senate intentionally let some figs from Africa drop to the ground when arranging his toga, and when the senate expressed admiration at their size and beauty, he told them that the region which produced the figs was only three days' journey by sea from Rome - the enemy was as close to Rome as that. Pliny goes on to say that it was through the agency of this fig that the decision to subjugate Carthage once and for all was taken. This anecdote is discussed by Meijer 1984: 117-124. 
artichokes for the dinners of the rich in Rome. In the hills to the west the famous Numidian horses were bred, ${ }^{15}$ and sheep for their wool.

Early in the 3rd century AD Tertullian (De Anima 30.3) gives the following description of the country: "Smiling estates have replaced the most famous deserts, cultivated fields have conquered the forests, flocks of sheep have put wild beasts to flight".

\subsection{The Pax Romana}

A second important reason for the prosperity of the North African provinces is the peace and stability in Africa in the $3^{\text {rd }}$ and $4^{\text {th }}$ centuries. Agriculture in particular can only flourish during settled conditions, and long-term planning was particularly important for cultivating the olive. Africa Proconsularis was what is termed a "proconsular province", a status given to provinces which were deemed absolutely safe, thus needing little or no military protection. In fact, for 400 years, right through Imperial times, North Africa had only one legion to protect it (the Legio III Augusta stationed at Lambaesis in Mauretania), although the region as a whole was a frontier province and much larger than Britain which had six legions.

The $3^{\text {rd }}$ and $4^{\text {th }}$ centuries were tempestuous times in the rest of the Empire, which was ravaged by wars, plundering and epidemics. In the half-century after the murder of Alexander Severus in 235 no fewer than 26 emperors were recognized in Rome, and civil wars between the contenders for the throne were waged all over the Empire with the concomitant economic repercussions, lasting well into the $4^{\text {th }}$ century. In the meantime storm clouds were already gathering on the horizon with the barbarian hordes from the North-East ascending on the Empire's frontiers, to culminate in the sack of Rome by Alaric and his Goths in $410 .{ }^{16}$ North Africa, on the contrary, was still peaceful and stable despite constant raids by barbarians tribes of the interior - in fact, it was the last province to be overrun by the barbarians.

\subsection{Enfranchisement, integration and ownership}

Another important factor contributing to the prosperity was the positive influence of the progressive enfranchisement of the Africans, and the integration of the settlers and the indigenous population.

Some time after the destruction of Carthage in the $2^{\text {nd }}$ century BC, a Roman colony had been established on Carthaginian soil, and at various stages during the next two centuries ex-soldiers and/or civilians were sent there as colonists. In the 40s of the $1^{\text {st }}$ century BC Julius Caesar enfranchised many African individuals - men of local importance who had served him well. He sowed, as it were, the seeds for the

15 They were used by Hannibal in the Second Punic War (the only battle that he ever lost was at Zama when the Numidian cavalry turned against him) and later with great success in battles by the Romans. Cf. Raven 1969: 69.

16 After the sack of Rome, Alaric marched south and intended to invade Africa to settle his people there, but a severe storm sank most of his fleet; during his retreat northwards he fell sick and died See Sinnigen \& Boak 1977: 454. 
rebirth of North Africa ${ }^{17}$ in being the first to realize the value of large-scale grants of citizenship, both for Rome and for the local population. Augustus (27 BC - AD 14) continued the policy and elevated towns with a long-standing Italian settler element to the status of municipium or colonia. This policy was also followed by the emperor Claudius (41-54) who was notorious for his lavish grants of citizenship. ${ }^{18}$ The growth in Africa in the $2^{\text {nd }}$ century, especially under Trajan (98-117) and Hadrian (117-138), was phenomenal, and reached its zenith under Septimius Severus (193-211).

The process of integration was helped by the fact that the settlers were usually greatly outnumbered by the local inhabitants. ${ }^{19}$ Furthermore, the social barrier between the civis Romanus and the peregrinus ${ }^{20}$ had by the $2^{\text {nd }}$ century AD gradually been replaced by wealth and Romanization as status symbols. The legal barrier was in any case lifted in AD 212 by the famous edict of Caracalla which gave Roman citizenship to all the free inhabitants of the Roman Empire. The indigenous population now had full legal equality with the Roman settlers and their descendants, intermarriage was legally possible and access to careers in Rome was open to all. By the beginning of the $3^{\text {rd }}$ century about one-sixth of the senators in Rome were of African origin.

The process of integration had as a result that by the end of the $2^{\text {nd }}$ century the town-dwellers, of whatever ethnic origin, considered themselves Roman-Africans; they were, as Thompson remarks (1969: 145), enthusiastic to become part of the Roman citizen-body, and "took pride simultaneously in their Graeco-Roman culture and their Africa roots". In turn, some descendants of Roman settlers even participated in African cults and gave their children Latinized Punic names (Thompson 1969: 145). In short, there was a fruitful fusion and integration and mutual influencing ${ }^{21}$ between the Roman settlers and their descendants, and the indigenous population over a long period of time. Thompson (1969: 142) states: "Racialism was foreign to the Roman mentality".

17 It was in the year of Caesar's assassination (44 BC) that Carthage was officially re-founded as a Roman city. Cf. Singor 2006: 69.

18 Cf. Seneca, Apoc. c.3: "He made up his mind ... to see the whole world in the toga, Greeks, Gauls, Spaniards, Britons, and all”.

19 In the $1^{\text {st }}$ century the Italian immigrants constituted but a small part of the population - the rest being descendants of the ancient Phoenicians, "Punicized" Libyans and Berbers, freedmen from the eastern Mediterranean, and veterans of the Legio III Augusta from Gaul and Spain, totaling about 5 million inhabitants. The ratio had changed by the late $2^{\text {nd }}$ century - Pikhaus 2006: 100 traced the degree of Romanization in Mactar, a medium-sized Punic-Numidian town by looking at inscriptions, and found 130 Punic inscriptions vs. 580 Latin ones.

20 A civis Romanus was a person with full Roman citizenship, while a peregrinus was a foreigner who did not have citizenship. This distinction led to great tension in the period following Rome's conquest in $146 \mathrm{BC}$, since the Roman settlers had the right to own land, while the local inhabitants could only enjoy the usufruct of (their) land which now belonged to Rome (Thompson 1969: 145).

21 This can clearly be seen in e.g. the syncretism occurring in the religion of the people of North Africa - the Semitic Astarte eventually became the Roman Venus but still retained much of her original oriental character, while Baal-Hammon became Saturn, but did not loose the dreaded power of Baal, thus Lancel 1995: 431; Mattingly \& Hitchner 1995: 207. 
A good example of such fusion is the family of the Severi from Lepcis Magna. Septimius Severus, a member of an indigenous African family, received Roman citizenship in the 1 st century $\mathrm{AD}$ In the $2^{\text {nd }}$ century his family was raised to the equestrian order; a member of this family, P. Septimius Geta, married Fulvia Pia, the daughter of a prominent Roman settler family of the same town. A son of this couple, Septimius Severus, became the first Roman emperor of African stock (Thompson 1969: 146-7).

With the social advancement these new Roman-African citizens took "ownership" of their country and embellished their cities with grandiose temples and magnificent public baths in the Roman manner. A kind of municipal snobbery in Africa even developed, with the new citizens trying to be more Roman than the Romans, e.g. in retaining the titulature of colonia and municipium long after the law of 212 had made it irrelevant, and also maintaining magistracies such as the duumviri and aediles and the flamines of the imperial cult when it was no longer used in the rest of the Roman world (Thompson 1969:147).

\section{Possible reasons for the disappearance of the Roman influence}

It is thus clear that the traditional view of the decline of the cities in the Roman Empire by the $4^{\text {th }}$ century AD does not apply to North Africa. On the contrary, its exceptional prosperity, unusual in comparison with the other Roman provinces of the time, was remarked on by various contemporaries, as has been shown. But even more unusual and more difficult to understand is the complete disappearance after the Arab conquest of all traces of Roman influence on the culture and language of the province. The Roman provinces in Europe (Gaul, Spain and Belgium) were, at the time when they were overrun by the barbarians, much less Romanized and less developed than North Africa, and yet Rome's heritage can be discerned in so many different aspects of their culture and language. In North Africa on the other hand, all that are left to remind one of nearly 600 years of Roman occupation (146 BC - AD 439) are the ruins of massive amphitheatres and other public buildings, silent witnesses of a period of unequalled prosperity in Roman provincial administration. In terms of the culture and language of North Africa, however, it is as if the Romans had never been there.

\subsection{The Vandal invasion}

A reason for the disappearance of Roman influence which immediately springs to mind, is the Vandal invasion of the $5^{\text {th }}$ century AD. The Vandals crossed the Strait of Gibraltar (80 000 men, women and children in small boats), landed somewhere in Morocco in 429 and steadily marched eastwards, seizing towns as they went along. The Roman general, Count Bonifacius, with his army went out to meet them but suffered a severe defeat. Reinforcements were eventually sent from Italy, but this new army was beaten even more decisively. Hereafter the Vandals quickly overran the rest of Africa. On 19 October 439 they arrived at the gates of Carthage, where the local population were, according to contemporary accounts, still cheering their teams in the 
Circus Maximus. ${ }^{22}$ The city was taken with little resistance. The fall of Carthage sent shock-waves through the western world, comparable to that following the sack of Rome in 410 . But life in the city went on, and despite the misery caused by the new regime, many of the local people remained and were active under Vandal domination. Some of the prosperity which marked the previous period, survived for a time.

The Vandals have the reputation of being destructive, "vandalistic" - could this be the reason why all traces of Roman influence vanished? On the contrary, this is one of the great misrepresentations of history. A closer examination of what really happened during the Vandal "interregnum" brings to light that they did not come to destroy, but were lured by the wealth of Africa and wanted to settle there. Greedy for booty, they did indeed ransack the rich Christian churches, confiscate rural domains, dispossess and in many cases exile the rich aristocratic landlords (many of whom fled to Italy and elsewhere), but they did not cut down the olive orchards or the vineyards and the countryside remained relatively well cultivated. Roman everyday life remained the same, Latin was made the official language, ${ }^{23}$ Roman coins continued to be used, and Roman engineers and architects were still employed for building projects. The Vandals respected Rome's rich cultural heritage and were anxious to be "Romanized". Of all the barbarians tribes invading Europe, the Vandals are said to have delighted most in the enervating luxuries of Roman civilized life - the baths, the feasts, spectacles in the amphitheatre and shows in the theatres.

The Vandal invasion brought an end to Roman domination, but this was not yet the end of Roman Africa - they conquered the province, but kept it Roman and would leave it Roman. Thanks to the prosperity of the $4^{\text {th }}$ century, the province survived, ${ }^{24}$ but the Roman heritage did suffer two fatal blows: the Vandals used, abused and enjoyed what they found useful, but replaced nothing and there was no upkeep; they did not take up the financial burdens of the towns, which meant that the fragile municipal system hitherto maintained administratively and financially by the upper classes, rapidly declined in the $5^{\text {th }}$ century. A second fatal blow was the decision of their king Genseric that all the cities should dismantle their protective city walls. This left them a prey to the depredations of the local Berber tribes which had never been Romanized, with the result that by the end of the $5^{\text {th }}$ century most of the frontier towns were deserted.

Less than a century later, North Africa was invaded again - this time by the Romans from the resurgent eastern half of the empire with its capital in Byzantium. They easily defeated the Vandals who were enervated after a century of Roman luxury, thereby realising the emperor Justinian's ideal of reuniting the eastern and

22 Cf. Quotvultdeus (Sermo de tempore barbarico I.1, P.L. 40,700). The addiction of the city to the pleasures of the circus and the theatre was regarded as a scandal by Salvian (De gub. Dei VI.69), who believed that the Vandal invasion was a just chastisement of Carthage, the African Babylon, sentenced for its vices (ibid. VII.13-17). In 409 already St. Augustine preached against such a series of spectacles in the amphitheatre, the theatre and the circus (En. in Ps. 80, 102, 103, 146, 147).

23 Raven 1969: 103 remarks that no Vandal words (their native language was Gothic) remained in the Berber vocabulary.

24 Despite the enormous loss of income after the cessation of the annona to Rome (Mattingly \& Hitchner 1995: 204). 
western halves of the Roman Empire. The Vandals simply disappeared, some fled to Spain, others remained and became integrated with the indigenous population. Only their name remained in the pejorative term "Vandalism", coined by an $18^{\text {th }}$ century bishop of Blois in France, saddling the Vandals with a reputation which they hardly deserve (Raven 1969: 167)

The Byzantines found themselves even less able to control the insurgent Berbers from the south and west who had grown audacious during the Vandal reign, and were thus ordered by Justinian to rebuild the city walls which Genseric had pulled down. Since this had to be done quickly, they simply used the neglected Roman temples and monuments as quarry, leaving many of these buildings in the sad state that we see today.

There was, however, a remarkable revival of the province of Africa Proconsularis under Byzantine rule - some scholars even call it a minor renaissance. ${ }^{25}$ North Africa remained Roman, and its language and literature was Latin. This was the language of the Church Fathers Cyprian, Lactantius and St. Augustine, whose Latin works played an important role in the Middle Ages. But the Byzantine revival merely postponed the final demise of North Africa - their eastern influence on the future inhabitants of North Africa was as ephemeral as that of the Vandals. However, the Byzantine period was important in that it provided a bridge linking one civilization to another: "the Arabs conquered not barbarians, but a generation of Africans who were still accustomed to the usages of civilization, to reading, writing, settled agriculture, the breeding of animals - they had in short not forgotten what the Romans had taught them" (Raven 1969: 178).

\subsection{Romanization merely a fragile superstructure?}

The view that the Romanization of North Africa was superficial and limited, should also be considered as a possible reason for the disappearance of Roman influence after the Arab conquest. Scholars such as Frend (1952), Courtois (1955) and Shaw (1980) are among those who believe that the Romanization in North Africa was only a veneer, a fragile superstructure affecting only the upper classes of a society which at its roots remained faithful to its pre-Roman traditions (the Berber customs and tribal structures). This view was recently corroborated by the French historian Claude Lepelley (1979: 20-1), who pointed out that systematic Romanization and urbanization only took place in what is now northern and central Tunisia and eastern Algeria; elsewhere it was limited - Roman cities were enclaves in the world of the rural Berber tribes. There was thus a great disparity between the different regions regarding the degree of Romanization and urbanization. The gap between the wealthy, urban Romanized people (many of whom were Africans) and the poorer,

25 The city walls were refurbished, the basilica on the Byrsa hill converted into a church, the city streets repaired, but the maintenance of the monuments, aqueducts and fortifications now devolved upon the (impoverished) cities. As regards new buildings, euergetism was now directed towards the founding of hospices, churches and monasteries. Cf. Mattingly \& Hitchner 1995: 212. 
less privileged rural Berbers was never bridged, and the alienation of the latter group was one of the reasons for the eventual disintegration of the province.

Linked to this is the fact that after the Vandal conquest, when most of the Roman landlords were dispossessed, many of them were among the thousands who fled the country (some went to France and Italy where the new rulers were less oppressive). The Arab invasion led to a similar exodus of the upper class who could afford to leave. This meant that the initially small nucleus of settlers and their descendants - the people who were the most Romanized and who would have upheld Roman values and culture - was becoming smaller with each wave of invaders. And after the Arab conquest North Africa became increasingly isolated from the rest of Europe, with little contact or communication with the outside world. Hereafter the fact of being so vastly outnumbered would have made the preservation of Roman values and the cultural heritage impossible for those who remained in Africa.

\subsection{The role of Christianity and the Church}

A final possible reason for the demise of Roman influence in North Africa may be found in the attacks on the Church from both within the Empire and beyond its borders. From the $4^{\text {th }}$ century when Christianity became the state religion, church and state became inextricably connected. The emperor became the head of the Church, and churchmen were gradually also put in charge of civic structures. Any changes in the religion would thus have shaken the whole structure of the state. This was especially true in Africa, which was in the late Empire the bastion of Christianity in the west. However, various factors were gradually undermining Christianity in Africa - Maureen A. Tilley (2001: 3-22) ${ }^{26}$ is of the opinion that the Church in North Africa was severely weakened well in advance of the Arab conquest (429-647).

Firstly, the Great Persecution of Diocletian in 303-5 had as result that the Church in Africa split in two. This so-called Donatist schism was to torment the country until the end of the Roman Empire, causing much unrest and bloodshed. ${ }^{27}$ Apart from this, the Church was also weakened from within by sectarian and class divisions - the clergy were hated by the poor because of their possessions (Isichei 1995: 42 n.93).

Then there was the persecution of the Christians by the Vandals with the decimation of the bishops either by exile or death; this left the Christian communities leaderless for long periods, all the more so since the Vandals prevented the vacancies in the various dioceses from being filled. ${ }^{28}$

In Byzantine times the persecution was stopped, but a new problem emerged when the emperor as the head of the Church started intervening in provincial matters. Justinian in particular exercised much greater control over ecclesiastical affairs than

26 Cf. also Botha 1986:24-32.

27 The basic reason for the schism was that over-orthodox Christians, called the Donatists after their leader Donatus, were not willing to accept priests who had renounced their faith during the persecutions, back into the fold, while the rest (the "Catholics") were more lenient in this respect (cf. in this regard Van Reisen 2006: 149-158.

28 Carthage e.g. was during the 94 years of Vandal period without a bishop - resident or in exile for 41 years (Tilley 2001: 13). 
the African bishops had been accustomed to, and enforced his interpretation of faith and order on the bishops to the extent of deposing or exiling them if they did not acquiesce. Many did indeed suffer this fate. These repeated challenges to episcopal authority led to a decline in the numbers and influence of the bishops, and left a vacuum into which Islam could easily step.

The last nail in the coffin was the mass conversion of the Berbers to Islam after the Arab conquest. The Islamicization of North Africa which now included the formerly alienated Berbers, proved to be far more lasting than Romanization had ever been. This is in stark contrast with the course of events in Europe, where the Church with its firm Roman structures and Latin language kept Roman influence alive.

\section{Conclusion}

By way of summary it can be said that although the Vandal conquest dealt the Roman inheritance a few hard blows, that was not the main reason why the Romans left no trace in North Africa. It is true that the Vandals consumed whatever they found in Africa without replacing it, but it was the Byzantines who in rebuilding the city walls caused the most destruction to the physical remains of Roman buildings.

I would ascribe the disappearance of Roman influence in Africa to two main factors: in the first place the flight of the Romanized African elite who still maintained Roman values and culture, making the small nucleus of those who would have upheld the Roman inheritance, even smaller. And this happened on two occasions, after the Vandal invasion and again after the Arab conquest. Secondly, the replacement of Christianity - which was by the $6^{\text {th }}$ century inextricably connected with the Roman State - by Islam, meant that the civic structures which were all still based on a Roman foundation, were seriously undermined. The Arabs took over the Roman inheritance, but gradually replaced it with their own Islamic culture and values - North Africa would flourish again under them, but not in a Roman way.

\section{BIBLIOGRAPHY}

Botha, C J 1986. The extinction of the Church in North Africa. Journal of Theology for South Africa 57: 24-32.

Courtois, C 1955. Les Vandales et l'Afrique. Paris.

Fentress, E 2006. Romanizing the Berbers. Past and Present 190: 3-34.

Frend, W H C 1952. The Donatist Church: A Movement of Protest in Roman North Africa. Oxford.

Graham, A 1902. Roman Africa. An outline of the history of the Roman occupation of North Africa. New York.

Isichei, E 1995. A history of Christianity in Africa. Michigan: Grand Rapids.

Jones, A H M 1964. The later Roman Empire 284-602. A social, economic and administrative survey. Vol. I. Oxford.

Lancel, S 1995. Carthage. A History. Oxford.

Lennox Manton, E 1988. Roman North Africa. London. 
Lepelley, C 1979. Les cités de l'Afrique Romaine au Bas-Empire. Tome I. La permanence d'une civilization municipale. Paris.

Mattingly, D J \& Hitchner, R B 1995. Roman Africa: an archaeological review. Journal of Roman Studies 85: 165-213.

Meijer, F J 1984. Cato's African Figs. Mnemosyne 37:117-124.

Pikhaus, D 2006. Romanisering in de praktijk. Het voorbeeld van Mactaris. Hermeneus 78.2: 99-107.

Raven, S 1969. Rome in Africa. London.

Rostovtzeff, M 1957. The Social and Economic History of the Roman Empire, $2^{\text {nd }}$ edition. Oxford.

Shaw, B D 1980. Archaeology and knowledge : the history of the African provinces of the Roman Empire. Florilegium 2: 28-60.

Singor, H W 2006. Africa Romana: een overzicht. Hermeneus 78.1: 65-78.

Sinnigen, W G \& Boak, A E R 1977. A history of Rome tot AD 565. $6^{\text {th }}$ edition. New York.

Thompson, L A 1969. Settler and native in the urban centres of Roman Africa. In L A Thompson \& J Ferguson (eds.), Africa in Classical Antiquity, Ibadan.

Tilley, M A 2001. The collapse of a collegial church: north African Christianity on the eve of Islam. Theological Studies 62: 3-22.

Van Reisen, H 2006. Tweespalt om Christelijke identiteit: donatisten en katholieken in Noord-Afrika. Hermeneus 78.2: 149-158.

Warmington, B 1954. The north African provinces from Diocletian to the Vandal conquest. Westport, Connecticut. 